\section{Evaluating the economic impacts of farm-to-school procurement: An approach for primary and secondary financial data collection of producers selling to schools}

Special JAFSCD Issue

Economics of Local Food Systems:

Utilization of USDA AMS Toolkit Principles

Sponsored by

FOOD SYSTEMS

colorado STATE university

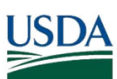

\author{
Libby Christensen ${ }^{\text {* }}$ * \\ Routt County Colorado State University Cooperative Extension
}

Becca B. R. Jablonski ${ }^{\text {b }}$

Colorado State University

Lacy Stephens ${ }^{\mathrm{c}}$

National Farm to School Network

Anupama Joshi d

Blue Sky Funders Forum

Submitted April 6, 2018 / Revised June 5, June 29, and July 10, 2018 / Accepted July 11, 2018 /

Published online D ecember 20, 2018

Citation: Christensen, L., Jablonski, B. B. R., Stephens, L., \& Joshi, A. (2019). Evaluating the economic impacts of farm-to-school procurement: An approach for primary and secondary financial data collection of producers selling to schools. Journal of A griculture, Food Systems, and Community D evelopment, 8(Suppl. 3), 73-94. https:// doi.org/ 10.5304/ jafscd.2019.08C.002

Copyright @ 2019 by the Authors. Published by the Lyson Center for Civic Agriculture and Food Systems. Open access under CC BY license.

\begin{abstract}
According to the U.S. D epartment of Agriculture's (USD A) Farm to School Census, during the 20132014 school year, $42 \%$ of all U.S. schools (5,254 districts including 42,587 schools) participated in

a * Corresponding author: Libby Christensen, Extension Agent, Routt County Colorado State University Cooperative Extension; $1366^{\text {th }}$ Street; Steamboat Springs, CO 80477 USA; +1-970-879-0825; lchristensen@ co.routt.co.us

b Becca B. R. Jablonski, Assistant Professor and Food Systems Extension Economist, D epartment of Agricultural and Resource Economics, Colorado State University; 1200 Center Avenue Mall; Fort Collins, CO 80523 USA; +1-970-491-6133; becca.jablonski@colostate.edu

c Lacy Stephens, Program Manager, National Farm to School Network; lacy@farmtoschool.org
\end{abstract}

farm-to-school activities. These programs included 23.6 million children and purchased almost US\$800 million of locally procured food items (USD A Food and Nutrition Services [USDA FNS], 2015). O ne of the purported benefits of farm-to-school procurement is that it strengthens the local economy by providing expanded market access for local farms and ranches. Despite the claims of positive

\footnotetext{
d Anupama Joshi, Executive D irector, Blue Sky Funders Forum (previously executive director and co-founder, National Farm to School Network); +1-847-917-7292; anupama@blueskyfundersforum.org
}

\section{Funding Disclosure}

This study was supported through generous funding from CoBank and AgriBank through a grant to the National Farm to School Network, a project of Tides Center. 
economic impact, there is limited research to support this. This paper presents a framework for evaluating the economic impacts of farm-to-school programs, adapting the USDA's "Local Food Economics Toolkit" for this specific context. The approach combines primary and secondary data to customize an input-output model, reflecting the complex supply chains that link producers and schools. Additionally, to illustrate the approach, we summarize the findings from two case studies of local food procurement by schools between 2016 and 2017.

\section{Keywords}

Farm-to-School, Food Systems, Economic Impact, Local Food Systems Toolkit

\section{Introduction}

Farm-to-school is broadly defined "as a schoolbased program that connects schools (K-12) and local farms with the objectives of serving local and healthy foods in school cafeterias or classrooms, improving student nutrition, providing health and nutrition education opportunities, and supporting small and medium-sized local and regional farmers" (Joshi, Azuma, \& Feenstra, 2008, p. 230). Farm-to-school implementation differs by location, but always includes one or more of the following core elements: (1) procurement of local foods to be purchased, promoted, and/ or served in the cafeteria or as a snack or taste-test; (2) education activities related to agriculture, food, health, or nutrition; and (3) school gardens (Christensen, Jablonski, Stephens, \& Joshi, 2017).

The first farm-to-school programs emerged in California, Connecticut, and Florida in the late 1990s (Feenstra \& O hmart, 2012; O hmart, 2002). The National Farm to School Network (2016) estimates that there were six programs in five states in 1997. By 2008, the number of programs had grown dramatically to more than 1,000 programs in 34 states (Kalb, 2008). Farm-to-school was officially incorporated into the federal child nutrition program through the Healthy, Hunger-Free Kids Act in 2010. According to the USD A's Farm to School Census, by the 2013-2014 school year, $42 \%$ of all
U.S. schools (5,254 districts that encompass 42,587 schools) participated in farm-to-school activities. These programs reached 23.6 million children and included almost $\$ 800^{1}$ million of locally procured food items, including milk, which accounts for $46 \%$ of local food expenditures by school districts (USD A FNS, 2015).

Some of the growth in the number of programs can likely be attributed to the proliferation of financial support and interest from private foundations and public agencies. These organizations provide funding for farm-to-school programs, at least in part due to the assumption that they contribute to positive regional economic development. D espite growing support, there has been limited research exploring the economic impact of farm-to-school activities, including whether its activities, such as local food procurement, strengthen local inter-industry linkages or expand market access for participating producers. While the authors recognize the importance of distinguishing between local and regional foods, most notably that local food is a necessary but not a sufficient component of regional food systems (Clancy \& Ruhf, 2010; Palmer et al., 2017), when discussing the geographic source for school food procurement, we use the term "local" as used by the USD A. This allows for the individual school or district to define local. When discussing economic impacts, we refer to the regional impacts and present a specific geographic boundary and justification for its selection. Further discussion about the relationship between the concept of regional food systems and defining the specific geographic boundaries of economic impact assessments, and the implications this has on the results, are presented in the results section.

To promote more standardized, rigorous assessments to evaluate market and economic outcomes of localized markets and/ or shorter supply chains, the USD A Agricultural Marketing Service (AMS) developed a best practice assessment methodology and a standardized replicable framework called the Local Food Economics Toolkit (henceforth 'Toolkit') (Thilmany McFadden et al., 2016). Utilizing the impact assessment approach outlined

${ }^{1}$ All currency in this paper is in US\$. 
in the Toolkit, we propose a methodology intended to expand our understanding of how school districts procure local foods and how these supply chains' structure changes the way in which participating farmers work with other businesses in their community (often referred to as inter-industry linkages) and how this impacts regional economics. We present results from two case studies, one in the Minneapolis School District and one in the state of Georgia. In both, we use a combination of primary data (collected from a limited number of producers engaged in selling to school districts) and secondary data (e.g., USD A's Farm to School Census, USD A's Agricultural Resource Management Survey, and IMPLAN) to customize an inputoutput model. Importantly, we consider opportunity cost, which represents the relationship between scarcity and choice. Put another way, opportunity costs are the benefits an individual or business misses out on as a result of selecting one alternative over another. O pportunity cost is often considered from the demand side. For example, if a school shifts a portion of its food purchases from a traditional wholesaler to direct purchases from a farm, the opportunity cost of that choice are the value of the displaced purchases from a traditional wholesaler. This paper contributes to the nascent literature evaluating the economic impacts of farmto-school activities and can also be used to inform efforts to assess the economic impact of similar local food procurement programs in colleges, hospitals, and early childcare and education settings.

The program used in this and many other economic impact analyses is IMPLAN. The IMPLAN software relies on an input-output (I-O) table that reflects the flow of economic linkages, namely the monetary exchanges associated with the trade of

Table 1. Hypothetical Input-Output Transaction Table

\begin{tabular}{lcccc}
\hline & Agriculture & Manufacturing & Final demand & Total output \\
\hline Agriculture & 150 & 500 & 350 & 1,000 \\
\hline Manufacturing & 200 & 100 & 1,700 & 2,000 \\
\hline Value added & 650 & 1,400 & & 2,050 \\
\hline Total outlays & 1,000 & 2,000 & 2,050 & \\
\hline
\end{tabular}

2 In the economic impact field, value added is the difference between an industry's output and its inputs. More details on IMPLAN's use of the term are at https:/ / implanhelp.zendesk.com/ hc/ en-us/ articles/ 115009498847-Value-added goods and services, within a specific geographic area at a moment in time. The I-O tables are based on regional and sometimes national averages from the U.S. D epartment of Commerce, the U.S. D epartment of Labor Statistics, USD A, and other federal and state government agencies. These linkages take the form of an expenditure function, which specifies how different inputs are assembled in order to produce a unit of output. Another way to think of the expenditure function is the sector's recipe to produce goods and services (output). So, an I-O table comprises columns that represent all the purchases and final demand, while the rows consist of all industry sales and value added ${ }^{2}$ (e.g., labor compensation, interest payments, and rental costs) for every industrial sector within a region's economy. Assume that a regional economy comprises only two industries: agriculture and manufacturing (Table 1).

In the economy represented in Table 1 , the agriculture sector purchases $\$ 150$ worth of goods and services from the agriculture sector and US $\$ 200$ worth of goods and services from manufacturing within the study region. The sector spends $\$ 650$ on payments to employees, holders of capital, and governments. The sum of entries in each column represent the total purchases by the industry. Since profits, losses, depreciation, taxes, etc., are included in the table as final payments, total purchases must equal total sales.

The I-O table is used to create an I-O model (Jablonski, Schmit, \& Swenson, 2016). D espite the utility of the I-O model in assessing short-term economic impacts, it has several limitations including its assumption of unlimited supply, constant prices, static framework, constant returns to scale, and fixed technology. The I-O model is demanddriven, meaning that there are no supply constraints. The model assumes that there is always excess capacdemand will be met- at the price for which it is currently available. Particularly in ity in the system and that any 
agriculture, where prices are extremely volatile, the assumption of constant prices can be highly problematic and serve to distort results (Swenson, 2006). The reason that constant prices are assumed is that I-O models are static, meaning that they capture a specific moment in time. Although this assumption is likely tenable in short-term analyses, it is unlikely that prices will not change in the medium- to long-term. D espite its limitations, I-O models and IMPLAN, if used thoughtfully, are a powerful tool for economic impact analysis.

Accordingly, there are many studies that use I-O models and IMPLAN to quantify the economic impacts and contributions of agriculture to county, regional, statewide, and national economies.

We begin this paper with a review of previous economic impact assessments of farm-to-school procurement programs, highlighting inconsistencies in the approach and rigor, followed by the presentation of our study methods using the Toolkit as a roadmap. We then go on to present findings from our survey of producers and discuss the results of our economic impact assessment. Finally, we discuss the implications for assessments of the impacts of local food procurement by schools and suggest opportunities for future work.

\section{Literature Review}

There are a handful of studies that assess the economic impacts of farm-to-school procurement (Gunter, 2011; Kane, Kruse, Markesteyn Ratcliffe, Ananda Sobell, \& Tessman, 2010; Kluson, 2012; Pesch, 2014; Roche, Becot, Kolodinsky, \& Conner, 2016; Tuck, Haynes, King, \& Pesch, 2010). Using the recommendations put forth in the Toolkit, we evaluated whether these studies incorporate key recommended components in their assessments (see Table 2). Specifically, we noted whether or not authors described (1) the geographic region and school district; (2) the type of study, specifically if the study is a contribution or impact assessment; (3) assumptions about how food moves from farm to school or the structure of the supply chain; (4) if or how they augmented or modified secondary data (such as that found within IMPLAN) based on interviews with farmers or other secondary data to more accurately reflect local and regional food system activities and farm expenditure patterns; and (5) if the study accounts for opportunity costs (Thilmany McFadden et al., 2016).

Schools generate economic activity through their purchases of goods and services in a regional economy, which in turn results in a series of additional purchases by the businesses from which they purchase products to supply the schools. These existing exchanges are part of a contribution assessment, while assessing whether the impact of a shift in school purchases from traditional food sources to more local sources would be an economic impact assessment.

G enerally, the more businesses within a specific region purchase from one another, the stronger the inter-industry linkages and resulting multiplier. The multiplier is a numeric way of describing the secondary impacts stemming from a change in the economy. The multiplier is the sum of the direct, indirect, and induced effects divided by the direct effect. The direct effect is associated with the change in industry spending. In the case of farm-to-school procurement, the direct effect is the change in the quantity or source of food produced within the region. The direct effect results in indirect effects, or changes in backward-linked industry purchases as other industry sectors respond to the new demands of the directly affected industries. The induced effects are the changes in spending from households as labor income is converted into household spending on local goods and services. The indirect and induced effects are influenced by the structure of the supply chain. For example, if the food is purchased directly from farmers, the indirect and induced effects will be different from those associated with a purchase of locally produced products through an intermediary because of the differences in reliance on labor and input requirements.

There are three types of multipliers: output, employment, and labor income. The output multiplier is the base multiplier from which all other multipliers are derived. It describes the total output generated as a result of one additional dollar of output generated by the target economic sector. For example, if an output multiplier is 1.25 , that means that every dollar of production in the specific economic sector generates an additional $\$ 0.25$ in the local economy. Similarly, the employment 
Journal of Agriculture, Food Systems, and Community Development ISSN: 2152-0801 online

multiplier describes the total jobs generated as a result of one job in the target economic sector. Finally, the labor income describes the dollars of labor income generated as a result of one a dollar of labor income in the target economic sector. While some of the papers presented in Table 2 include all three multipliers, most did not, so we have limited our comparison to the output multiplier.

With the exception of Haynes (2010), G unter and Thilmany (2012), and Roche et al. (2016), the studies reviewed do not describe how food travels from the farm to the school. O nly Roche et al. (2016) include intermediate local food sales in their assessment. The structure of the supply chain can have important implications for modeling the economic impacts of procurement. For example, USD A Foods are the single largest source of ingredients for schools, and about half of those foods are diverted for processing prior to delivery (Woodward-Lopez et al., 2014). If these foods are replaced with products from local sources, the economic impact assessment must address a number of questions, such as will processing occur on the farm, at a local processor, or in the schools? What implications will changes in the processing location have on employment requirements (i.e., will lighter processing at the farm require additional labor in

Table 2. Summary of Farm-to-School Economic Impact Assessment Studies (all currency in US\$)

\begin{tabular}{|c|c|c|c|c|c|c|}
\hline Study & $\begin{array}{l}\text { Haynes, 2010, and } \\
\text { Tuck, Haynes, King, } \\
\& \text { Pesch, } 2010\end{array}$ & $\begin{array}{l}\text { Kane, Kruse, } \\
\text { Ratcliffe, Sobell, \& } \\
\text { Tessman, } 2010\end{array}$ & $\begin{array}{l}\text { Gunter, 2011, and } \\
\text { Gunter \& Thilmany, } \\
2012\end{array}$ & Kluson, 2012 & Pesch, 2014 & $\begin{array}{l}\text { Roche, Becot, } \\
\text { Kolodinsky, \& } \\
\text { Conner, } 2016\end{array}$ \\
\hline Location & Minnesota & Oregon & Colorado & Florida & Minnesota & Vermont \\
\hline $\begin{array}{l}\text { Model geographic } \\
\text { scale }\end{array}$ & $\begin{array}{l}\text { 5-county region } \\
\left(5,600 \mathrm{mi}^{2}\right)\end{array}$ & $\begin{array}{l}\text { State of Oregon } \\
\left(98,000 \mathrm{mi}^{2}\right)\end{array}$ & $\begin{array}{l}2 \text {-county region } \\
\left(6,500 \mathrm{mi}^{2}\right) \text { and } \\
6 \text {-county region } \\
\left(13,500 \mathrm{mi}^{2}\right)\end{array}$ & Unspecified & $\begin{array}{l}\text { 12-county region } \\
\left(23,890 \mathrm{mi}^{2}\right)\end{array}$ & $\begin{array}{l}\text { Statewide }(9,600 \\
\left.\mathrm{mi}^{2}\right)\end{array}$ \\
\hline $\begin{array}{l}\text { Size of school } \\
\text { district }\end{array}$ & $\begin{array}{l}\text { Cass, Crow Wing, } \\
\text { Morrison, Todd, } \\
\text { and Wadena } \\
\text { counties } \\
\text { (20,840 } \\
\text { students) }\end{array}$ & $\begin{array}{l}\text { Portland Public } \\
\text { Schools ( } 47,000 \\
\text { students) and } \\
\text { Gervais school } \\
\text { district (1,500 } \\
\text { students) }\end{array}$ & $\begin{array}{l}\text { Weld } 6 \text { Greeley } \\
\text { (19,500 students) }\end{array}$ & $\begin{array}{l}\text { Sarasota School } \\
\text { District }(42,000 \\
\text { students) }\end{array}$ & $\begin{array}{l}68 \mathrm{~K}-12^{\mathrm{a}} \text { schools } \\
\text { and } 396 \text { health- } \\
\text { care facilities } \\
(66,900 \text { students })\end{array}$ & $\begin{array}{l}\text { Vermont ( } 94,000 \\
\text { students) }\end{array}$ \\
\hline Type of study & $\begin{array}{l}\text { Impact (three } \\
\text { scenarios: one } \\
\text { special meal, } \\
\text { unprocessed } \\
\text { substitution, } \\
\text { substitute all) }\end{array}$ & $\begin{array}{l}\text { Impact } \\
(\$ 462,000)\end{array}$ & $\begin{array}{l}\text { Contribution } \\
\text { and impact } \\
(\$ 20,900- \\
\$ 39,125 \text { in } \\
\text { planned } \\
\text { purchases) }\end{array}$ & $\begin{array}{l}\text { Contribution } \\
\text { (\$107,000 in } \\
\text { existing } \\
\text { purchases) }\end{array}$ & $\begin{array}{l}\text { Contribution } \\
\text { ( } \$ 33,000 \text { worth } \\
\text { of sales) and } \\
\text { impact }(20 \% \text { of } \\
\text { all institutional } \\
\text { food purchases } \\
\text { from local } \\
\text { growers) }\end{array}$ & $\begin{array}{l}\text { Contribution } \\
\text { (\$914,943 existing } \\
\text { purchases) and } \\
\text { impact (three } \\
\text { scenarios: } \\
\text { increases in } \\
\text { purchases) }\end{array}$ \\
\hline $\begin{array}{l}\text { Supply chain } \\
\text { structure }\end{array}$ & Direct & Not specified & Direct & Not specified & Not specified & $\begin{array}{l}\text { Combination of } \\
\text { direct and } \\
\text { intermediated }\end{array}$ \\
\hline $\begin{array}{l}\text { Customization of } \\
\text { IMPLAN agricultural } \\
\text { sectors }\end{array}$ & $\begin{array}{l}\text { Yes, using } \\
\text { survey data }\end{array}$ & No & $\begin{array}{l}\text { Yes, using survey } \\
\text { and secondary } \\
\text { data }\end{array}$ & No & No & No \\
\hline Sample size & 11 farmers & $\begin{array}{l}\text { No farmers } \\
\text { interviewed }\end{array}$ & 14 farmers & $\begin{array}{l}\text { No farmers } \\
\text { interviewed }\end{array}$ & $\begin{array}{l}\text { No farmers } \\
\text { interviewed }\end{array}$ & $\begin{array}{l}\text { No farmers } \\
\text { interviewed }\end{array}$ \\
\hline $\begin{array}{l}\text { Includes opportunity } \\
\text { costs (shift in } \\
\text { purchases from } \\
\text { wholesaler to food } \\
\text { producer) }\end{array}$ & $\begin{array}{l}\text { Assumes no } \\
\text { loss to current } \\
\text { wholesalers } \\
\text { because they } \\
\text { are not in the } \\
\text { region }\end{array}$ & No & $\begin{array}{l}\text { Subtracts the } \\
\text { impact of the } \\
\text { wholesale sector } \\
\text { from the farming } \\
\text { sector }\end{array}$ & No & $\begin{array}{l}\text { Assumes a loss } \\
\text { of } 75 \% \text { of total } \\
\text { new sales to the } \\
\text { wholesale sector }\end{array}$ & $\begin{array}{l}\text { Margins purchases } \\
\text { shifted from } \\
\text { wholesale and } \\
\text { transportation } \\
\text { sector to direct } \\
\text { from producers }\end{array}$ \\
\hline Output multiplier & $1.03-1.25$ & 1.86 & $1.47-1.63$ & 2.4 & $1.7-2.9$ & 1.6 \\
\hline
\end{tabular}

a $\mathrm{K}-12$ refers to schools ranging from kindergarten to twelfth grade.

Note: 1 square mile $\left(\mathrm{mi}^{2}\right) 2.6$ square $\mathrm{km}$

Source: Adapted from Becot, Kolodinsky, Roche, Zipparo, Berlin, Buckwalter, \& McLaughlin (2017). 
the school to prepare the food for student consumption)? Further, while Haynes (2010) and Tuck et al. (2010) acknowledge a decrease in demand for ingredients from more traditional sources (USD A Foods, wholesalers, etc.), they do not account for the opportunity costs because all the distributors were located outside the geographic boundary. Gunter (2011), Pesch (2014), and Roche et al. (2016) attempt to account for the lost sales to intermediaries as a result of the local food purchases.

Primary data collection through farmer surveys or interviews can shed light on the structure of the supply chain. O nly two studies (G unter, 2011; Haynes, 2010) collected primary data from farmers. Primary data is useful to inform and modify the expenditure functions in IMPLAN. The two studies with primary data collection were also the only two studies to customize the IMPLAN agricultural sectors. Not accounting for the different linkages associated with farms that sell to school is a significant shortcoming of the studies that did not modify IMPLAN. As noted in the Toolkit, the industry data presented in IMPLAN is a rich starting point, but the economic activities are derived from national averages, aggregated for an entire commodity or industry sector. This often limits the extent to which local food-system activities can be accurately analyzed. Changes in the expenditure function and local purchasing percentage (the percent of all economic exchanges between two sectors of the economy that occur within the geographic area of interest) can have significant impacts on the multiplier (Schmit, Jablonski, \& Mansury, 2016). A side from the relationships that exist between the producer and the consumer (schools, in the case of farm-to-school procurement), there are a host of additional, often stronger linkages that exist between farms that sell through local channels and other sectors of the regional economy. Previous research suggests that these farms spend a larger proportion of their total expenditure in the regional economy, particularly on labor, relative to more commodityoriented producers (Bauman, Thilmany McFadden, \& Jablonski, 2018; Jablonski, Schmit, \& Kay, 2016; Thilmany McFadden et al., 2016).
Y et finding data to reflect these linkages often adds significant time and cost to conducting the study. The approach presented and utilized in the next section provides a more standardized and efficient method for primary data collection to allow for a more accurate evaluation of the economic impacts of a school or district's shift to local food procurement.

Surveys and interviews can be used to better understand farmers' motivations or hesitation to participate in farm-to-school programs. The inclusion of farmers' perspectives is surprisingly sparse in the farm-to-school literature, despite as pointed out by Conner, King, Kolodinsky, Roche, Koliba, and Trubek (2012), "farms are by definition an indispensable component of FTS [farm-to-school]; if farmers are unable to participate or derive no benefit, the potential benefits of FTS will not be realized" (p. 322). Much of the farm-to-school literature focuses on the perspective of school foodservice operations (Vogt \& Kaiser, 2008). The farm-to-school studies that include farmer surveys observe a tension between economic and noneconomic forces (Berkenkamp, 2012; Conner et al., 2012; Izumi, Alaimo, \& Hamm, 2010; Izumi, Wright, \& Hamm 2010a; 2010b; Matts, Conner, Fisher, Tyler, \& Hamm, 2016). As Izumi, Wright, and Hamm (2010a) summarize, "from a purely economic perspective, farm-to-school programs appear to be a relatively insignificant opportunity for farmers" (p. 379). Conner et al. (2012) found that an array of social and economic motivations underpin farmers' participation in farm-to-school programs. These studies helped to inform the development of our survey instrument and resulted in the inclusion of two open-ended questions concerning the non-economic motivation and impact of selling to schools.

All the studies we reviewed found that the output multiplier associated with farm-to-school procurement was greater than that associated with the existing agricultural production sector, although only modestly. As is generally the case with regional economic impact studies, studies with smaller geographic bounds show smaller economic impacts, illustrating the importance of selecting an appropriate functional economic area (Thilmany McFadden et al., 2016). All the studies used 
political and/ or school district boundaries to define the functional economic area. The functional economic area should cover a relatively contained and cohesive network of trade that includes the places where people live, work, and shop. The studies reported output multipliers that varied from 1.03 in a study of six counties in Minnesota (Haynes, 2010) to 2.4 in Florida with an unspecified functional economic area (Kluson, 2012).

\section{Methods}

This study roughly followed the seven modules presented in the Toolkit: (1) frame the assessment process, (2) use secondary data sources, (3) generate and use primary data, (4) engage your community process with the data, (5) analyze linkages and contribution through input-output analysis, (6) address opportunity costs, and (7) conduct an advanced IMPLAN analysis.

M odule 1. F raming the assessment process We started by framing our community economic assessment process by working collaboratively with researchers from Colorado State University (CSU) trained in economic impact assessment methods and leaders from the National Farm to School Network (NFSN). Together, we gathered resources including white papers, journal articles, and previous economic impact assessments. We also collected survey protocols from researchers across the country who surveyed farmers and school district foodservice directors about farm-to-school procurement programs. After reviewing the resources, we defined the study objectives to document the short-term economic impacts of farm-to-school sales, apply a best practice economic impact assessment methodology, and develop a standardized, replicable framework to assess the regional economic impact of a school or school district's shift to local food procurement.

As part of Module 1, framing the process, which occurred roughly between August and December 2016, we also reached out to FoodCorps to partner with individuals already embedded in school districts who could assist with data collection. Nine volunteers (from Indiana; Detroit, Michigan [MI]; Traverse City, MI;
Greensboro, North Carolina [NC]; the Bay Area of California; Washington, D .C.; G reeley, Colorado [CO ]; Pueblo, CO; and Newark, New Jersey [NJ]) offered to take the lead on data collection in their communities. In the beginning of December 2016, CSU provided a webinar training and practice survey to ensure consistency across enumerators.

\section{M odules 2 and 3 . U sing secondary data and} generatingl using primary data Modules 2 and 3 occurred simultaneously and informed one another. We used a combination of primary and secondary data to investigate farm-toschool sales and market linkages. Best-practice economic impact assessments of farm-to-school food procurement require information from producers or available and relevant secondary sources to inform model data and assumptions (Thilmany McFadden et al., 2016). Specifically, the goals of data collection were to (1) provide descriptive data about the type of farms selling to schools, including information about producer level of satisfaction with those transactions; (2) understand if or how farmers shifted their operations based on the availability of school markets (for example, did they increase production, did they shift product from one market to another); and (3) estimate an average farm expenditure profile that could be multiplied by the total number of farms in the study area selling to schools to create a new farmto-school industry sector in IMPLAN.

The primary data used in this study was collected using a survey of a convenience sample of producers currently selling to schools. The survey was developed collaboratively by CSU and NFSN and included 20 questions that asked farmers about their production practices, sales, markets, overall satisfaction with selling to schools, and participation in various farm-to-school activities (see the Appendix). The instrument was explicitly designed to be as short as possible while still eliciting the information needed for customizing the model, enhancing our understanding of how to define the functional economic area based on where producers were selling their products, and calculating potential opportunity costs. It also included two questions to capture the non-economic impacts of selling to schools. The survey focused on six 
general expenditure categories that account for $66 \%$ of all variable expenditures for all local farmers and ranchers with gross cash farm income up to $\$ 350,000$ as estimated in the USD A's 2013 Agricultural Resource Management Survey (ARMS) (USDA Economic Research Service [USD A ERS], 2015). The ARMS is an annually conducted, nationally representative survey of approximately 30,000 farms, and includes data on gross cash farm income, marketing channels utilized, key product segments, region where operation is located, fixed and variable expenses, assets, debt, and farm and operator characteristics.

For the sake of brevity, our survey did not include questions about the local purchasing percentage (LPP) - the share of input purchases from sources within the functional economic area. We used IMPLAN coefficients as a secondary data source, which we expected to result in a more conservative multiplier, as local producers are more likely to purchase inputs locally (Jablonski, Schmit, \& Kay, 2016; Pesch \& Tuck, 2015). We created average expenditure functions for producers in the two case study sites using responses from the survey, which we then compared to an aggregate fruit and vegetable farming sector in IMPLAN.

We test-piloted the survey with six farm-toschool stakeholders before launch. The research was conducted in accordance with CSU's Human Research Protection Program and was deemed exempt (IRB\#288-17H). NFSN staff and FoodCorps fellows and alumni conducted the producer surveys. Twenty-six producers selling to schools in nine states ( $\mathrm{G}$ eorgia, Indiana, Michigan, Minnesota, New Jersey, North Carolina, Pennsylvania, Utah, and Wisconsin) and the D istrict of Columbia completed the survey. D escriptive statistics for all 26 producers are presented in this paper, but due to the very small sample size, only data from the two locations with the highest number of responses (Minnesota and G eorgia, with five and six completed responses, respectively) were used to test the expenditure data collection tool and to demonstrate how a more generalizable, representative sample could be used to support best-practice economic impact assessments.
M odule 4. E ngaging your community process with data Throughout the process of data collection, we convened the project leadership team to review the incoming data and findings. Along the way, we had to revisit the limitations of project resources balanced with the difficulties associated with data collection. Because of the limited capacity of FoodCorps volunteers, the NFSN staff took on great responsibility with data collection and targeted specific communities to ensure we had enough responses to build a model. D uring this time we also began to organize efforts around different avenues and approaches to present the key findings from the study to our community.

In the fall of 2017, working with our team and additional partners from USD A Agricultural Marketing Service, USDA Food and Nutrition Service, and Cornell University, we organized a webinar on the key findings from the study and other resources to support stakeholder efforts at assessing the economic impact of local food projects and initiatives. Using engaging figures, tables, and graphics helped us to communicate key findings from our study and highlight next steps for farmto-school research across the country. ${ }^{3}$ Over 300 people registered for the webinar, and there have been over 150 views of the recorded webinar on YouTube.

M odules 5. A nalyzing the link ages and contribution through input-output analysis O ne of the first steps in creating an I-O model is to properly specify the functional economic area. With our case study approach, we had to define the study area for each site. The Minneapolis Public Schools (MPLS) serves the city of Minneapolis, Minnesota. Nearly 37,000 students are enrolled in the 96 public primary and secondary schools in the district (National Center for Education Statistics [NCES], 2017). According to the 2013-2014 Farm to School Census, 63 schools within the district sourced local fruits, vegetables, milk, meat, and/ or poultry for their breakfast and lunch meal programs. Products were sourced directly from producers and through intermediaries (food hubs, distributors, and food manufacturers) (USD A FNS,

${ }^{3}$ See a factsheet from the project at http:// www.farmtoschool.org/ Resources/EconomicImpacts-FactSheet.pdf 
2015). D uring that same year, the district spent a total of $\$ 7,842,090$ on food, with $13 \%$ spent on local food (excluding milk). The district defines local as within a 200-mile (322-km) radius, including 163 counties in four states, which we used as our study area. We collected survey responses from five fruit and vegetable producers selling directly to the MPLS. The five farms were widely dispersed. One producer was located on the western border of the state, and two producers were in Wisconsin. The remaining two were located just south of Minneapolis.

For this study, we estimated that there are 32 farmers selling to MPLS. This calculation was made by dividing the total local food purchases by MPLS $(\$ 1,057,880)$ by the average farm-to-school sales $(\$ 33,205)$ from the five surveyed farms.

The state of G eorgia, our second case study, covers 180 public school districts, $62 \%$ of which participate in farm-to-school. According to the 2013-2014 Farm to School Census, 82 districts sourced local foods for meal programs in 615 schools serving 1,226,410 students. Seventy-three districts sourced local products through an intermediary, 32 districts sourced directly from producers, and no districts sourced through food hubs. Total food cost data was available for 61 of the 82 districts and indicate that a total of $\$ 170,622,272$ was spent on all food. The 54 districts spent a total of $\$ 10,266,746$ (excluding milk) on local food.

Extrapolating the school expenditure patterns to all the districts in G eorgia that source local food, we assumed that the 82 districts are spending $\$ 229,361,086$ on total food and $\$ 15,590,243$ on local food (excluding milk). Survey data were collected from six fruit and vegetable producers within the study area. For the purposes of this study, it was estimated that there are 92 farms selling to schools in Georgia, which were calculated by dividing the total local food purchases by $\mathrm{G}$ eorgia schools $(\$ 10,266,746)$ by the average farm-toschool sales $(\$ 110,407)$ from the six surveyed farms. The regional (and thus our study area) was defined as all 159 counties in the state.

M odule 6. A ddressing opportunity costs As noted in the literature review, opportunity costs are often overlooked in economic impact assessments of farm-to-school procurement. If a school is going to increase its overall expenditures on local food, it may do so through a one-time influx of dollars (i.e., foundation award, grant, or donation), or it may decide to shift spending permanently away from something else. In general, a school is unlikely to increase its average per student expenditure (other than adjusting for inflation) based on a desire to purchase local food. So, new local purchases will almost certainly supplant nonlocal purchases. Understanding how local food purchases impact other school purchases is key to conducting a rigorous and accurate economic impact assessment. The degree of the changes will be influenced, at least in part, by the structure of the supply chain. If farmers and school districts choose to enter in a direct relationship, there will likely be reduced purchases through intermediaries (including businesses that might be local). Although it may be tempting to try to maximize the result or multiplier impact when conducting an economic impact assessment, rigorous research must measure net impacts. The goal should be to get as accurate an estimate as possible of how local or regional economies respond based on new or shifted economic activity. In these case studies, to account for the opportunity costs of local food purchases, new farm-to-school purchases (including direct and intermediated, margined for the intermediary mark-up) were subtracted from the total expenditure of the aggregated fruit and vegetable production sector and the wholesale sector.

M odule 7. M odifying IM PL A N

The final step outlined in the USD A AMS Toolkit provides information on how to adjust the default settings in IMPLAN to create a model that is more reflective of the conditions on the ground. Using the primary and secondary data described above, we created a customized expenditure pattern for producers selling to schools in each of our case study sites. We then compared these estimated expenditure patterns, after accounting for the sale of the items minus the cost of the goods purchased from wholesalers and retailers (this is called the margined value and must be done for purchases from retail and wholesale sectors), to the secondary data from ARMS and IMPLAN to verify that they 
were reasonable in comparison to aggregated fruit and vegetable expenditure function (Table 3). We then created a sales profile for producers, recognizing that farm-to-school producers often rely on a variety of markets for their products and that many of the sales to schools are in fact traveling through an intermediary. As stated in the previous section, in the MPLS region producers sold on average $\$ 33,205$ to schools; $50 \%$ was sold directly to schools and $50 \%$ was sold through intermediaries. In G eorgia, producers sold on average $\$ 110,407$ to schools; $45 \%$ was sold directly, and $55 \%$ went through intermediaries.

We then assigned the local purchasing percentage (LPP) using IMPLAN numbers to create our customized IMPLAN model.

Using the six largest expenditure categories, we captured $68 \%$ of the Minneapolis farmers' variable costs and $73 \%$ of the $\mathrm{G}$ eorgia farmers'. What may be most surprising, particularly in G eorgia, is how similar the survey data is to the IMPLAN data, particularly labor.

Unlike other farm-to-school economic impact studies, this study tried to reflect the fact that farmers rely on a variety of markets for their products. The model thus accounted for direct-to-consumer sales, intermediated sales, and direct-to-school sales.

Once the model in IMPLAN was customized to reflect the new farm-to-school production sector, we conducted the economic impact assessment. A scenario was developed for each of the case studies to evaluate the impact that an increase in final demand for local products by schools would have on the study area. This increase in final demand is referred to as the "shock," or the direct impact. Secondary data sources including press releases, newspaper articles, the 2013-2014 USDA Farm to School Census, the National Farm to School Network website, and farm-to-school grant and funding information were reviewed to develop realistic scenarios.

\section{Results}

F armer Survey D escriptive Statistics

Of the 26 farmers interviewed, 20 grew vegetables, 13 produced fruit, and two also raised livestock.

There was substantial heterogeneity in terms of the size of the farm operations. The farms ranged in size from half an acre ( $0.2 \mathrm{ha})$ to 500 acres (202 ha). The average farm size was 69 acres (28 ha). The farms' total sales ranged from $\$ 9,500$ per year to $\$ 8$ million, with the average sales being $\$ 920,000$. All the farms started selling to schools after 2005, with the majority starting after 2011.

As part of our effort to understand how farmers responded to the availability of school markets, we asked them why they started selling to schools. Their responses fell into four broad categories: (1) provided a market, (2) opportunity to educate youth, (3) approached by school, and (4) already selling to an intermediary that began to sell to a school. Ten farmers expressed that schools

Table 3. Share of Variable Costs Attributed to the Top Six Expenditure Categories

\begin{tabular}{lcccccc}
\hline Expenditure category & $\begin{array}{c}\text { ARMS local } \\
\text { food farmers } \\
\text { (sales up to } \\
\$ 350,000)\end{array}$ & $\begin{array}{c}\text { ARMS farm-to- } \\
\text { school farmers }\end{array}$ & $\begin{array}{c}\text { IMPLAN MSLP } \\
\text { fruit and } \\
\text { vegetable } \\
\text { farmers }\end{array}$ & $\begin{array}{c}\text { MSLP farm-to- } \\
\text { school farmers }\end{array}$ & $\begin{array}{c}\text { IMPLAN Georgia } \\
\text { fruit and } \\
\text { vegetable } \\
\text { farmers }\end{array}$ & $\begin{array}{c}\text { Georgia farm-to- } \\
\text { school farmers }\end{array}$ \\
\hline Labor & 0.12 & 0.29 & 0.41 & 0.47 & 0.27 & 0.27 \\
\hline $\begin{array}{l}\text { Fertilizer and chemical } \\
\text { inputs }\end{array}$ & 0.11 & 0.12 & 0.13 & 0.03 & 0.10 & 0.23 \\
\hline Fuel and transportation & 0.12 & 0.09 & 0.05 & 0.03 & 0.06 & 0.05 \\
\hline Maintenance and repair & 0.14 & 0.11 & 0.05 & 0.06 & 0.06 & 0.05 \\
\hline Utilities and rent & 0.09 & 0.09 & 0.04 & 0.04 & 0.05 & 0.05 \\
\hline Seeds & 0.08 & 0.09 & 0.02 & 0.04 & 0.02 & 0.07 \\
\hline All other variable costs & 0.34 & 0.22 & 0.31 & 0.31 & 0.43 & 0.26 \\
\hline
\end{tabular}

Source: USDA ERS (2015); IMPLAN (2013). ARMS data compiled by Allie Bauman, Colorado State University. 
provided a needed market for a product, which is in line with the findings from Izumi, Wright, and Hamm (2010a). One farmer explained, "We grow a lot of good keeping winter apples that harvest late and our retail business slows after the end of October, so we need a market for them." Seven farmers expressed that farm-to-school sales provided a unique opportunity to educate youth about healthy food options and agriculture, and another seven farmers stated they started selling to schools because they had been approached by someone at the school. Three farms noted that they had already been selling to an intermediary that just started selling to schools and that it was not an active decision on their part.

We asked the farmers a number of questions to better understand how farm-to-school sales fit into their overall operation and relatedly, the general structure of the supply chain linking producers and schools. In line with Joshi et al.'s (2008) findings, direct farm-to-school sales accounted for a modest portion of all farm sales, which was 13\% of sales from our surveyed producers. In addition to direct sales to schools, the farms relied on a diversity of other outlets, including direct to consumer (20 farms); intermediated (e.g., supermarket or supercenter; restaurant or caterer; other retail store; local or regional food processor or food maker; or local or regional aggregator, distributor, food hub, or broker) (16 farms); wholesale marketplace for commodities not identified by source (e.g., auction, wholesale or terminal market) (10 farms); and institutions (e.g., colleges, hospitals, prisons) (5 farms). Three of the farms surveyed had no direct sales to schools, but instead sold to schools exclusively through an intermediary. Twelve farms noted that some of the product they sell to intermediaries ends up at schools. Understandably, some farmers struggled to estimate the percent of their intermediated products sold to schools; as one farmer explained, "My food hub doesn't share that information."

Direct sales from farm to school represent different inter-industry linkages within a local economy than sales from farm to intermediary to school. According to the 2013-2014 Farm to School Census, $65 \%$ of school districts buy local food through a distributor. Christensen, Jablonski, and O'Hara (2017) found that schools that purchase local products directly from farms and/ or nontraditional distributors spend significantly less per student on non-milk local food purchases. The fact that intermediaries facilitate the majority of farm-to-school transactions also poses new challenges for identifying producers engaged in farmto-school sales and measuring supply and demand for local foods in schools.

\section{E conomic Impad A ssessment}

Once the model in IMPLAN was customized using our primary and secondary data to reflect the new farm-to-school production sector, we conducted the contribution assessment. Results from the model, incorporating the data collected from the survey, show a gross output multiplier of 1.93 in MPLS and 2.11 in G eorgia (Table 3). This indicates that for every additional dollar spent on local food procurement by schools (accounting for no opportunity cost), an additional $\$ 0.93$ for related sectors is generated in the MPLS study area and \$1.11 in the $\mathrm{G}$ eorgia study area. We see that the multipliers are larger in both examples for our farm-to-school production sector compared to the average fruit and vegetable production sector, yet it should be noted that we are working with a very limited number of observations.

We created a shock for both study areas to evaluate the economic impact of an increase in final demand for local products by schools. For the MPLS case study, we modeled the impact of a $\$ 25,000$ grant from the Center for Prevention at Blue Cross Blue Shield in Minnesota using an analysis-by-parts approach. We assumed that the awarded grant enabled the district to shift some of their non-local food purchases to local food purchases. The $\$ 25,000$ in farm-to-school purchases follows the supply chain structure modeled using a combination of primary and secondary data. For this case study, we assumed that $50 \%$ of the sales are directly purchased from the grower, while 50\% are purchased through an intermediary. Based on the default data in IMPLAN, we assumed a 17\% margin for the wholesale trade sector (which includes food intermediaries).

Thus, the grant of $\$ 25,000$ results in $\$ 22,875$ worth of purchases from the farm-to-school 
production sector, with $\$ 2,125$ of the grant value going toward covering the wholesale trade sector margin, which is allocated to the levels of intermediated purchases and value added outlays necessary to support the farm-to-school production sector ( $\$ 8,443$ is allocated to employee compensation and $\$ 2,297$ to proprietor income). This approach also allows for a 10\% mark-up between the price of local goods as compared to the nonlocal goods, as it is assumed that the district is spending $\$ 22,875$ for the same amount of product that they previously purchased for $\$ 20,750$, when they purchased all of the food through the wholesale trade sector.

Next, we needed to take into account the opportunity cost associated with this shift. As a result of the $\$ 22,875$ increase in local food purchases, the school purchased $\$ 20,750$ less of nonlocal food products. The loss of these sales to the aggregated fruit and vegetable sector and the wholesale sector are the opportunity costs. Because this is a regional economic impact model, this study was only concerned with the loss of sales to the fruit and vegetable producers within the functional economic area; this is calculated using IMPLAN's LPP 21\% for the MPLS non-farm-toschool production sector. The shift from nonfarm-to-school products to farm-to-school products would result in a loss of $\$ 4,250$ in outlay to the wholesale sector. This loss is made up in part, because based on the survey findings it is assumed that $50 \%$ of the local product is still traveling through an intermediary, resulting in a net loss to the wholesale sector of $\$ 2,125$.

Table 4 shows the summary of the impact with and without the opportunity cost. For every additional employee added to the Minneapolis farm-to-school production sector's payroll, an additional 0.1 jobs are generated in backward-linked industries (that is, the employment multiplier is 1.1). Because only $\$ 22,875$ of the total grant
Table 4. Summary of Impact Results for MPLS Study Area, With and Without Opportunity Costs

\begin{tabular}{|c|c|c|c|c|}
\hline Impact type & Employment & Labor income & Value added & Output \\
\hline \multicolumn{5}{|c|}{ With opportunity costs } \\
\hline Direct effect & 1.00 & $\$ 8,443$ & $\$ 2,297$ & $\$ 22,875$ \\
\hline Indirect effect & 0.00 & $\$ 48$ & $(\$ 931)$ & $\$ 31$ \\
\hline Induced effect & 0.10 & $\$ 3,322$ & $\$ 5,808$ & $\$ 10,298$ \\
\hline Total effect & 1.10 & $\$ 11,813$ & $\$ 7,174$ & $\$ 33,204$ \\
\hline Implied multiplier & 1.10 & 1.40 & 3.12 & 1.45 \\
\hline \multicolumn{5}{|c|}{ Without opportunity costs } \\
\hline Direct effect & 1.00 & $\$ 8,443$ & $\$ 2,297$ & $\$ 22,875$ \\
\hline Indirect effect & 0.10 & $\$ 3,655$ & $\$ 4,880$ & $\$ 7,742$ \\
\hline Induced effect & 0.10 & $\$ 4,367$ & $\$ 7,633$ & $\$ 13,534$ \\
\hline Total effect & 1.20 & $\$ 16,465$ & $\$ 14,810$ & $\$ 44,151$ \\
\hline Implied multiplier & 1.20 & 1.95 & 6.45 & 1.93 \\
\hline
\end{tabular}

amount of $\$ 25,000$ is going to the farm-to-school production sector, we estimate that the new labor income increases by $\$ 11,813$, including the $\$ 8,443$ of the original output that went toward employment, plus an additional \$3,332 in indirect and induced income. The initial $\$ 25,000$ grant results in $\$ 22,875$ worth of new farm-to-school sales, which in turn generates $\$ 33,204$ of output impact when all indirect and induced effects are considered, resulting in an implied multiplier of 1.45 .

For the G eorgia study area, we took the same approach. We modeled the impact of a recent grant of $\$ 62,000$ to purchase more local foods. We modeled the pathway of the $\$ 62,000$ through the supply chain based on our survey results. We assumed that $55 \%$ of the sales are directly purchased from the grower, while the remaining $45 \%$ is purchased through an intermediary. Thus, the grant of $\$ 62,000$ results in $\$ 57,257$ worth of purchases from the farm-to-school production sector, which is allocated to the levels of intermediated purchases and value added outlays necessary to support it $(\$ 9,890$ is allocated to employee compensation, and $\$ 20,498$ to proprietor income). Again, to account for the opportunity cost associated with the shift in school food purchases, we assumed that the school supplanted non-local food with local food products. As a result of the $\$ 57,257$ increase in local food purchases, the school purchased $\$ 51,460$ less 
of non-local food products. Again, we assumed the school would purchase the same quantity of food no matter the source. As this is a regional economic impact model, the study is only concerned with the loss of sales to non-farm-to-school farms within the functional economic area; this is calculated using IMPLAN's LPP 25\% for G eorgia's aggregated fruit and vegetable production sector. The shift from the purchase of non-local to local food products would result in a loss of $\$ 10,540$ in output to the wholesale sector. This loss is made up in part, because based on survey findings, the model assumes $45 \%$ of the sales to the farm-toschool production sector still goes through an intermediary, resulting in a net loss to the wholesale sector of $\$ 5,797$. Table 5 shows the summary of the impact with and without accounting for opportunity costs. As illustrated below, when accounting for the opportunity costs, for every additional employee added to the farm-to-school production sector's payroll, an additional 0.5 jobs are generated in backward-linked industries (employment multiplier of 1.5). Similar to the calculations for the grant awarded to the MPLS region, the initial $\$ 62,000$ grant results in $\$ 57,275$ worth of new sales to farm-to-school farms, generating over $\$ 84,581$ of output impact when all indirect and induced effects are considered, resulting in an implied multiplier of 1.48.

Table 5. Summary of Impact Results for the Georgia Study Area, With and Without Opportunity Costs

\begin{tabular}{llccc}
\hline Impact type & Employment & Labor income & Value added & Output \\
\hline \multicolumn{5}{c}{ With opportunity costs } \\
\hline Direct effect & 1.00 & $\$ 9,890$ & $\$ 20,498$ & $\$ 57,275$ \\
\hline Indirect effect & 0.20 & $(\$ 3,879)$ & $(\$ 1,448)$ & $\$ 3,622$ \\
\hline Induced effect & 0.30 & $\$ 7,739$ & $\$ 13,715$ & $\$ 23,684$ \\
\hline Total effect & 1.50 & $\$ 3,860$ & $\$ 32,765$ & $\$ 84,581$ \\
\hline Implied multiplier & 1.50 & 0.39 & 1.60 & 1.48 \\
\hline \multicolumn{5}{l}{ Without opportunity costs } \\
\hline Direct effect & 1.00 & $\$ 9,890$ & $\$ 20,498$ & $\$ 57,275$ \\
\hline Indirect effect & 0.20 & $\$ 11,294$ & $\$ 16,245$ & $\$ 26,501$ \\
\hline Induced effect & 0.30 & $\$ 12,134$ & $\$ 21,497$ & $\$ 37,124$ \\
\hline Total effect & 1.50 & $\$ 23,428$ & $\$ 58,240$ & $\$ 120,900$ \\
\hline Implied multiplier & 1.50 & 2.37 & 2.84 & 2.11 \\
\hline
\end{tabular}


sector categories. As far as we know, this is the first study to more accurately characterize the farm-to-school production sector using primary data, taking into account the supply chain through which schools procure local products. The survey instrument is a valuable first step for communities, school districts, and others interested in evaluating the economic impacts of farm-to-school procurement and is available on the National Farm to School Network's website.

However, in this study researchers encountered a significant challenge in the implementation of the survey protocol, which is worth discussing. Lead researchers sought to enroll volunteer enumerators with strong relationships with producers to allay any potential concerns about participating in the survey. But we were not able to provide financial compensation for their time in the surveying effort. Without this and/ or buy-in from their supervisors, volunteers had little incentive to invest the time and effort necessary to conduct this type of primary data collection. For future studies, we recommend that enumerators be compensated for survey implementation. If not, surveys should be conducted in communities where the research team already has strong relationships with producers in order to elicit prompt and complete responses. If this barrier is appropriately addressed, farm-toschool stakeholders across the country can begin to use this survey tool to collect standardized data that would allow for comparisons across geography of both the farm-to-school farm expenditure profile as well as the percent of sales that are traveling direct from producers versus through intermediaries.

Through the primary data collection for this study, we found that in both case study areas, at least $50 \%$ of the school's local food purchases were through an intermediary. This poses new challenges for those seeking to measure the economic impact of farm-to-school procurement. The first challenge is around finding producers who sell to schools. As reported in the Farm to School Census, $65 \%$ of schools report purchasing at least some of their local food products through intermediaries, and thus producers may not know if their product is ending up in schools. This additional step in the supply chain may also reduce transparency for the schools, as encapsulated by a foodservice director's response to the 2013-2014 USDA Farm to School Census: "We have a management company, not sure who they purchase from" (USDA FNS, 2015). Furthermore, for many actors on either end of the supply chain, keeping records is onerous. As one foodservice director put it, "I don't keep separate records for local foods and couldn't imagine how I would go back to get this info. My guess isn't close to being accurate, so shouldn't be used at all. If you want this info, you should ask us to set up a system in advance" (USDA FNS, 2015). Some regions are considering developing their own inventory management tools so that schools have a better sense of the total value of their local food purchases as well as their different sources. There are also discussions underway for including questions related to the changing structure of the farm-to-school supply chain in the next Farm to School Census.

It is important to note that although implementing local food procurement programs in schools may create new market opportunities for some farms, it also displaces non-farm-to-school product purchases by schools, potentially negatively impacting other producers as well as intermediaries. These opportunity costs need to be accounted for in rigorous economic impact assessments. Further, the opportunity costs may have important consequences when considering the stated goals of farm-to-school programs. If, for example, the goal of farm-to-school procurement is to strengthen local and regional economies, then the findings herein could suggest that there is an advantage to sourcing through intermediaries. However, if the goal of farm-to-school procurement is to increase the economic viability of small and medium-sized producers, further investigation is needed into the relationship between farm profitability and supply-chain structure.

Economic impact data is valuable in engaging new and diverse stakeholders in farm-to-school initiatives, but may not be appropriate in all settings. The expansion of local and regional food markets has brought with it an increased interest in quantifying the extent to which these programs, including 
farm-to-school, contribute to economic development (O'Hara \& Pirog, 2013). Community and economic developers often employ multipliers to quickly and succinctly communicate the impact of these programs, but the emphasis on brevity may oversimplify the complexity of these systems. Further, advocates for local food systems may be tempted to present larger-than-accurate multipliers to overstate the economic impact of local foods systems. Those using the tools presented in this paper should, as D eller et al. (2017) suggest, proceed with caution. Collecting sufficient data to conduct credible modification of IMPLAN and adequately account for potential opportunity costs are difficult (Conner et al., 2016; D eller et al., 2017).

Growing evidence on the potential positive community economic impacts resulting from farmto-school procurement creates an opportunity to increase the engagement of farmers and farmfocused organizations. Economic data is also valuable in speaking to federal, state, and local agencies, as well as private investors and philanthropic entities. Positive economic outcomes offer justification and support for investment in local food purchasing and infrastructure that facilitates increased spending on local food. Both community-level infrastructure (e.g., aggregation and processing facilities, transportation) and school- or district-level infrastructure (e.g., equipment and capacity for processing and production) must be in place for local procurement to be feasible and sustainable. Both public and private investments in infrastructure are vital for local procurement opportunities to grow to scale and achieve the economic impact and viability demonstrated in the two case studies highlighted in this paper.

The economic impacts of farm-to-school procurement will continue to be a topic of interest for researchers, farm-to-school stakeholders, and policy-makers, and the authors hope that this study has sparked a deeper understanding of their challenges and opportunities. The preliminary results from the two case studies strengthen the call for those farm-to-school stakeholders with strong relationships to local producers to use the USDA Toolkit to conduct additional assessments evaluating the economic impacts of farm-to-school procurement, so that we may compare case studies in different locations, involving different commodities, scales, and numbers of producers, and relying on different supply chains. The survey protocol and methodology can support more rigorous and comparable economic impact assessments of farmto-school procurement moving forward, and thus fill an important gap in knowledge and open new opportunities for farm-to-school implementation and advocacy.

\section{References}

Bauman, A., Thilmany McFadden, D ., \& Jablonski, B. B. R, (2018). The financial performance implications of differential marketing strategies: Exploring farms that pursue local markets as a core competitive advantage. A griaultural and Resource E conomics Review,128. https:/ / doi.org/ 10.1017/ age.2017.34

Becot, F., Kolodinsky, J. M., Roche, E., Zipparo, A. E., Berlin, L., Buckwalter, E., \& McLaughlin, J. (2017). D o farm-toschool programs create local economic impacts? C hoices, 32(1), 1-8. https:/ / www.jstor.org/ stable/ 90014634

Berkenkamp, J. (2012). G rower perspectives on farm to school: A survey of interested farmers, ranchers and other producers. Minneapolis, Minnesota: Institute for Agriculture and Trade Policy. Retrieved from https:// www.iatp.org/ documents/ grower-perspectives-on-farm-to-school

Christensen, L. O ., Jablonski, B. B. R., Stephens, L., \& Joshi, A. (2017). E wnomic impacts of farm to school: Case studies and assessment tools. National Farm to School Network. Retrieved from http:/ / www.farmtoschool.org/ Resources/ EconomicImpactReport.pdf

Christensen, L. O., Jablonski, B. B. R., \& O'Hara, J. K. (2017). School districts and their local food supply chains. Renewable A griculture and F ood Systems, 1-9. https:/ / doi.org/ 10.1017/ S1742170517000540

Clancy, K., \& Ruhf, K. (2010). Is local enough? Some arguments for regional food systems. Choies, 25(1), 1- 5. Retrieved from http:// purl.umn.edu/ 93827

Conner, D ., Becot, F., \& Imrie, D . (2016). Critical reflections on the USD A local food economics toolkit. Journal of A griculture, Food Systems, and Community D evelopment, 7(2), 117-125. https:/ / doi.org/ 10.5304/ jafscd.2017.072.001 
Conner, D ., King, B., Kolodinsky, J., Roche, E., Koliba, C., \& Trubek, A. (2012). You can know your school and feed it too: Vermont farmers' motivations and distribution practices in direct sales to school food services. A griculture and H uman V alues, 29(3), 321-332. https:/ / doi.org/ 10.1007/ s10460-012-9357-y

Deller, S. C., Lamie, D ., \& Stickel, M. (2017). Local food systems and community economic development. Community D evelopment, 45(5), 612-638. https:/ / doi.org/ 10.1080/ 15575330.2017.1373136

Feenstra, G., \& O hmart, J. (2004). Y olo C ounty farm-to-school project evaluation year two annual report, 2003-2004. Retrieved from http:/ / www.farmtoschool.org/ Resources/Yolo\%20county\%20annual\%20report\%2004.doc

Gunter, A. (2011). Rebuilding local food systems: Mark eting and economic implications for communities (Master's thesis). Retrieved from https:// dspace.library.colostate.edu/ bitstream/ handle/ 10217/49814/G unter colostate 0053N 10765.pdf

Gunter, A., \& Thilmany, D . (2012). Economic implications of farm to school for a rural Colorado community. Rural Connections, W inter, 13-16. Retrieved from https:/ / wrdc.usu.edu/ files-ou/ publications/ pub 9857945.pdf

Haynes, M. (2010). Farm-to-school in C entral M innesota - A pplied economic analysis. University of Minnesota - Twin Cities Applied Economics D epartment. Retrieved from http:/ / www.regionfive.org/ cms/ files/ Farm\%20to\%20School\%20in\%20Central\%20MN\%20-\%20Applied\%20Economic\%20Analysis.pdf

IMPLAN. (2013). IMPLAN Professional (Version 3.0). Huntersville, North Carolina: IMPLAN.

Izumi, B. T., Alaimo, K., \& Hamm, M. W. (2010). Farm-to-school programs: Perspectives of school food service professionals. Journal of N utrition E ducation and Behavior, 42 (2), 83-91. https:/ / doi.org/ 10.1016/ j.jneb.2008.09.003

Izumi, B. T., Wright, D. W., \& Hamm, M. W. (2010a). Market diversification and social benefits: Motivations of farmers participating in farm to school programs. Journal of Rural Studies, 26(4), 374-382. https:/ / doi.org/ 10.1016/j.jrurstud.2010.02.002

Izumi, B. T., Wright, D. W., \& Hamm, M. W. (2010b). Farm to school programs: Exploring the role of regionally-based food distributors in alternative agrifood networks. A griculture and $\mathrm{H}$ uman $\mathrm{V}$ alues, 27(3), 335-350. https:// doi.org/ 10.1007/ s10460-009-9221-x

Jablonski, B. B. R., Schmit, T. M., \& Kay, D . (2016). Assessing the economic impacts of food hubs on regional economies: A framework that includes opportunity cost. A griaultural and Resource E conomics Review, 45(1), 143-172. https:// doi.org/ 10.1017/ age.2016.9

Jablonski, B. B. R., Schmit, T. M., \& Swenson, D . (2016, O ctober). A dvanoed training: E valuating the economic impacts of local and regional food systems using input-output analysis. Presentation at the Pre-Conference FD RS Workshop, New O rleans, LA. Retrieved from https:// localfoodeconomics.com/ oldbenchmarks/ fdrs/

Joshi, A., Azuma, A. M., \& Feenstra, G. (2008). D o farm-to-school programs make a difference? Findings and future research needs. Journal of $\mathrm{H}$ unger \& E nvironmental N utrition, 3(2-3), 229-246. https:// doi.org/ 10.1080/ 19320240802244025

Kalb, M. (2008). National farm to school network takes root. Community Food Security N ews, 1, $1 \& 12$.

Kane, D ., Kruse, S., Markesteyn Ratcliffe, M., Anada Sobell, S., \& Tessman, N. (2011). The impact of seven cents. Portland, O regon: Ecotrust. Retrieved from https:/ / ecotrust.org/ media/ 7-Cents-Report FINAL_110630.pdf

Kluson, R. A. (2012). Regional and local economic impacts of the Sarasota County farm to school program [Fact sheet]. University of Florida Extension and Sarasota County. Retrieved from https:// sfyl.ifas.ufl.edu/ media/ sfylifasufledu/ sarasota/documents/pdf/ag/ SarasotaCounty_FarmtoSchoolEconom icImpact.pdf

Matts, C., Conner, D. S., Fisher, C., Tyler, S., \& Hamm, M. W. (2016). Farmer perspectives of farm to institution in Michigan: 2012 survey results of vegetable farmers. Renewable A griaulture and F ood Systems, 31(1), 60-71. https:/ / doi.org/ 10.1017/ S1742170514000465

National Center for Education Statistics (NCES). (2017). D istrict D irectory Information [D atabase]. Retrieved from https:// nces.ed.gov/ ccd/ districtsearch/

National Farm to School Network (NSFN). (2016). Growth of farm to school in the U.S. (1997-2014) [Graphic]. Retrieved from http:// www.farmtoschool.org/ resources-main/ growth-of-Farm-to-School-in-the-u-s-1997-2014graphic 
O'Hara, J. K., \& Pirog, R. (2013). Economic impacts of local food systems: Future research priorities. Journal of A griculture, F ood Systems, and Community D evelopment, 3(4), 35-42. https:/ / doi.org/ 10.5304/ jafscd.2013.034.003

O hmart, J. L. (2002). D irect mark eting to schools: A new opportunity for family farmers. Retrieved from http:/ / asi.ucdavis.edu/ programs/ sarep/ publications/ food-and-society/ directmarketing-schools-2002.pdf

Palmer, A., Santo, R., Berlin, L., Bonanno, A., Clancy, K., Giesecke, C., . . Rocker, S. (2017). Between global and local: Exploring regional food systems from the perspectives of four communities in the U.S. Northeast. Journal of A griculture, F ood Systems, and Community D evelopment, 7(4), 187-205. https:/ / doi.org/ 10.5304/ jafscd.2017.074.017

Pesch, R. (2014). A ssessing the potential farm-to-institution mark et in œentral and northeast M innesota: A $n$ analysis of the mark et potential of locally raised foods by educational and healthcare institutions in 12 œntral and northeast Minnesota counties. University of Minnesota. Extension. Extension Center for Community Vitality. Retrieved from http:/ / hdl.handle.net/ 11299/171633

Pesch, R., \& Tuck, B. (2015). Financial benchmarks of local food operations: A study of financial performance of 11 commercial vegetable operations in C entral M innesota. University of Minnesota. Retrieved from http:/ / hdl.handle.net/ 11299/ 197831

Roche, E., Becot, F., Kolodinsky, J., \& Conner, D . (2016). E cnomic contribution and potential impact of schools purchase of local foods in V ermont. Center for Rural Studies, University of Vermont. Retrieved from http:/ / agriculture.vermont.gov/ sites/ ag/ files/CRS Economic\%20Contribution\%20of\%20Farm\%20to\%20School FINAL.pdf

Schmit, T. M., Jablonski, B. B. R., \& Mansury, Y. (2016). Assessing the economic impacts of local food system producers by scale: A case study from New York. E conomic D evelopment Q uarterly, 30(4), 316-328. https:/ / doi.org/ 10.1177/ 0891242416657156

Swenson, D . A. (2006). Input-outrageous: The economic impacts of modern biofuels production. Iowa State University. Retrieved from http:// www2.econ.iastate.edu/ research/ webpapers/ paper_12644.pdf

Thilmany McFadden, D ., Conner, D., D eller, S., Hughes, D ., Meter, K., Morales, ... Tropp, D . (2016). The economics of local food systems: A toolkit to guide community discussions, assessments and choiøes. U.S. D epartment of Agriculture, Agricultural Marketing Service. Retrieved from https:// www.ams.usda.gov/ sites/ default/ files/media/ EconomicsofLocalFoodSystemsToolkit.pdf

Tuck, B., Haynes, M., King, R., \& Pesch, R. (2010). The economic impact of farm-to-school lunch programs: A Central Minnesota ex ample. University of Minnesota Extension. Retrieved from http:/ / hdl.handle.net/ 11299/ 171560

U.S. D epartment of Agriculture, Economic Research Service (USD A ERS). (2015). 2013 Agricultural Resource Management Survey Phase III.

U.S. D epartment of Agriculture Food and Nutrition Services. (USD A FNS). (2015). 2013-2014 farm to school census respondent D ata. Version 10.31.16_web ed. Washington, D.C. Retrieved from https:/ / farmtoschoolcensus.fns.usda.gov/ sites/ default/ files/ asset/ document/ 2015\%20F2S\%20Census\%20SFA\% 20Data 6.27.16 web.xlsx

Vogt, R. A., \& Kaiser, L. L. (2008). Still a time to act: A review of institutional marketing of regionally-grown food. A griaulture and $\mathrm{H}$ uman V alues, 25(2), 241-255. https:/ / doi.org/ 10.1007/ s10460-007-9106-9

Woodward-Lopez, G., Kao, J., Kiesel, K., Miller, M. L., Boyle, M., D rago-Ferguson,. . Crawford, P. (2014). Is scratchcooking a cost-effective way to prepare healthy school meals with US D epartment of Agriculture foods?. Journal of the A cademy of N utrition and D ietetics, 114(9), 1349-1358. https:/ / doi.org/ 10.1016/j.jand.2014.05.002 


\section{Appendix. Farmer Survey Protocol}

Q1.1 Survey enumerator name:

Q1.2 The National Farm School Network (NFSN) is collaborating with researchers from Colorado State University (CSU) to conduct a study of the economic impact of farm to school programs. The research aims to understand how selling to the school food market impacts farm sales and profitability. During this survey, we will ask you questions to better understand the nature of your business and any changes you might have made since selling to schools. We do not anticipate any risks from participating in this research. No farm specific information will be shared with anyone outside of the Colorado State University-led research team without your permission. We will hold all information about your farm in strict confidence. The information will only be released in an aggregated format where individual farm information cannot be identified. We may quote your responses to open-ended questions, but your identity will not be associated with any quotes. Please be assured that we are committed to the strictest standards of confidentiality. If you have any questions, please feel free to call or email the Principal Investigator or Project Manager at any time.

If you have any questions or concerns regarding your rights as a subject in this study, you may contact the Institutional Review Board (IRB) for Human Participants at 970-491-1553 or access their website at https:// vprnet.research.colostate.edu/RICRO/irb/.

Q1.3 If you agree to participate in the study, please provide your name, farm name, telephone, email below and zip code where your primary farm is located.

- $\quad$ Name (1)

- Farm (2)

- Phone (3)

- Email (4)

- Zip code where your primary farm is located (5)

Q2.1 Why did you/ your farm decide to sell product to schools?

Q2.2 What impact(s) has selling to schools had on your business?

Q3.1 What is the name of the school district(s) to which you sell products? Please include city and state.

- District 1 (1)

- $\quad$ District $2(2)$

- $\quad$ District $3(3)$

- District $4(4)$

- District 5 (5)

- District 6 (6)

- $\quad$ District 7 (7)

Q3.2 In what year did you start selling to schools (e.g., k-12, preschool, early care and education facility, etc.)?

- $\quad$ Year (1) 
Q3.3 In 2016, which of the following products did you produce on your farm? Please check all that apply.

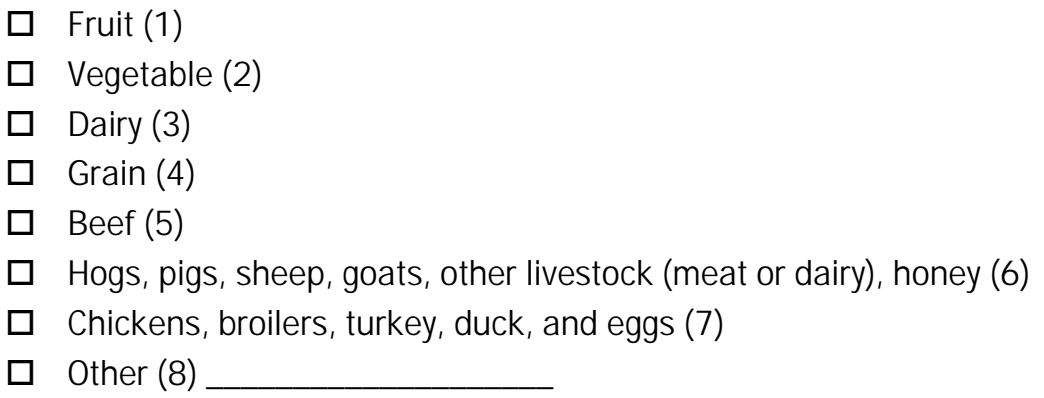

Q3.4 In 2016, did your farm utilize any season extension techniques (e.g., greenhouse, high-tunnels, hoophouse, etc.)?
○ Yes (1)
○ No (2)

\section{Display This Question [Q3.5]:}

If "yes" is selected.

Q3.5 Do you sell these products to schools? In other words, did participation in farm to school stimulate interest in or ability to utilize season extension techniques?
○ Yes (1)
○ No (2)

Q3.6 How many acres did you cultivate:

- When you started selling to schools: (1)

- In 2016: (2)

Q3.7 Did participation in farm to school stimulate changes in the amount of cultivated acreage?

○ Yes (1)

○ No (2)

Q3.8 Which of the following farm to school activities did you engage in during 2016 ?

Sold locally produced foods to be served in the cafeteria. (1)

- Participated in farmer in the classroom sessions/ cooking demonstrations of locally produced foods in the cafeteria, classroom or other school-related setting (2)

Hosted student field trips to your farm/ business (3)

$\square$ Provided school with marketing/ promotional materials about your farm (4)

$\square$ Donated product to school for sample or tasting for free or at a reduced price (5)

$\square$ Worked with school/ district staff to develop a specific food product using local foods (6)

$\square$ Were there any I did not mention (please specify): (7) 
Display This Question [Q3.9]:

If "Participated in farmer in the classroom sessions/cooking demonstrations of locally produced foods in the cafeteria, classroom or other school-related setting" "Hosted student field trips to your farm/ business" is selected

Q3.9 Which (if any) of the below themes did you cover with the students as part of your classroom and/or field trip engagement?

Life on a farm (1)

$\square$ Lessons on specific produce (what is this? why is it good for me?) (2)

$\square$ How food gets from the farm to the plate (3)

$\square$ The importance of farms to the environment (4)

$\square$ Were there any I did not mention (please specify): (5)

Q4.1 What percent of your 2016 farm sales came from each of the sales channels listed below? (total must equal 100)

Direct to farm to school (including k-12 and pre-k/ early care and education sites) (1)

Direct to individual consumer (e.g., farmers' market; on-farm store or farm stand; CSA; online market place; pick your own) (2)

Intermediated market (e.g., supermarket or super center; restaurant or caterer; other retail store; local or regional food processor or food maker; or local or regional aggregator, distributor, food hub, or broker) (3)

Institution (e.g., college or university; hospital) (4)

Wholesale marketplace for commodities not identified by source (auction, wholesale or terminal market, etc). (5)

Q4.2 Specifically, which of the following markets did your farm or ranch use in 2016? (please check all that apply)

Direct to $k-12$ schools (1)

$\square$ Direct to preschool or early care and education facilities (2)

$\square$ Farmers' markets (3)

$\square \quad$ On-farm store or farm stands (4)

$\square$ Community Supported Agriculture (CSA) (5)

$\square$ Online market place (6)

$\square$ Pick Your Own (7)

Supermarkets or supercenters (8)

$\square$ Restaurants or caterers (9)

$\square$ Other retail stores (independently owned grocery store, food cooperative, small food store, corner store, etc.) (10)

Local or regional food processors or food manufacturers (11)

Distributors (12)

$\square$ Food buying cooperatives (13)

$\square$ Food hubs (14)

Food service management companies (15) 
$\square$ DoD Fresh Program Vendors (16)

$\square$ USDA Foods (17)

State farm to school program office (18)

$\square$ Colleges or universities (19)

$\square$ Hospitals (20)

Other institutions (corporate cafeteria, prison, food bank, senior care facility, etc.) (21)

Wholesale marketplaces for commodities not identified by source (auction, wholesale or terminal market, etc). (22)

Q4.3 Does any of the product you sell through intermediaries end up at schools? If yes, what percent of your total intermediated sales goes to schools?
$\bigcirc$ Yes (1)
○ No (2)
○ Don't know (3)

Q4.4 Please tell us a bit more about your 2015 sales.

- TOTAL 2015 Sales (including all sales) (1)

- 2015 sales to schools (k-12 or pre-school) (2)

Q4.5 What was your level of satisfaction (very unsatisfied, unsatisfied, neutral, satisfied, or very satisfied) with the following aspects of your farm to school sales?

\begin{tabular}{|c|c|c|c|c|c|}
\hline & $\begin{array}{c}\text { very } \\
\text { unsatisfied } \\
(1)\end{array}$ & $\begin{array}{c}\text { unsatisfied } \\
(2)\end{array}$ & neutral (3) & satisfied (4) & $\begin{array}{c}\text { very satisfied } \\
\text { (5) }\end{array}$ \\
\hline $\begin{array}{c}\text { Prices paid (1) } \\
\text { Volume of sales (2) } \\
\text { Ordering reliability } \\
\text { (3) }\end{array}$ & 0 & 0 & 0 & 0 & 0 \\
$\begin{array}{c}\text { Time commitment } \\
\text { (4) }\end{array}$ & 0 & 0 & 0 & 0 & 0 \\
$\begin{array}{c}\text { Delivery } \\
\text { requirements (6) } \\
\text { Delivery logistics } \\
\text { (5) }\end{array}$ & 0 & 0 & 0 & 0 & 0 \\
$\begin{array}{c}\text { Reliable payment } \\
\text { (7) }\end{array}$ & 0 & 0 & 0 & 0 & 0 \\
$\begin{array}{c}\text { Ease of } \\
\text { communication } \\
\text { with schools (9) }\end{array}$ & 0 & 0 & 0 & 0 & 0 \\
$\begin{array}{c}\text { Overall profitability } \\
\text { (8) }\end{array}$ & 0 & 0 & 0 & 0 & 0 \\
\hline
\end{tabular}


Q4.6 When your farm started to sell to schools, how did it affect your production for and/ or sales to other markets? (please check all that apply)

We increased production to accommodate school sales (1)

We decreased sales to one or multiple direct markets (e.g., farmers' markets, CSA, farm stand, etc.) (2)

We lacked adequate market access for our firsts (e.g., highest quality products) before selling to schools (3)

We lacked adequate market access for our seconds (e.g., farm to school create an opportunity to sell our seconds/ imperfect products) before selling to schools (4)

We were a new/ beginning farm without pre-existing markets when we started selling to schools (5)

We started selling at schools so long ago that I can't remember (6)

$\square$ Other (7)

Q4.7 Do you plan to continue selling to schools in the future?

○ Yes (1)

- Maybe/Unsure (2)

○ No (3)

Q5.1 What were your total farm product sales and operating expenses for 2016 (January 1-December 31).

- Total farm product sales (1)

- Total farm operating expenses (2)

Q5.2 In 2016, approximately what percent of your farm or ranch's total expenditures were devoted to the following categories? (the sum of these expenses should not equal more than $100 \%$ ) Labor (according to the USDA the average labor expenses were $12 \%$ of total expenses) (1) Fertilizers and chemicals (average expenses were 11\%) (2) Maintenance and repair (average expenses were 14\%) (3) Fuel and oil (average expenses were 12\%) (4) Rent and utilities (average expenses were 9\%) (5) Seeds and plants (average expenses were 8\%) (6)

Q6.1 Thank you for your participation in this research! 